Kirił Marinow (Łódź)

\author{
Kirił Marinow (Łódź)
}

\title{
Asparuh and His People on the Lower Danube THROUgh THE EYES OF THEOPHANES, OR A STORY THAT WAS Not MEANT TO Happen
}

\begin{abstract}
$\Delta$ uthors of medieval historical texts often crafted a specific image of the past they were recounting. They strived not only to describe a given event but also to present it in an appropriate light, interpreted in a particular way. It was no different in the case of Byzantine historians and chroniclers ${ }^{1}$. In the context of Bulgarians' migration to the Balkan Peninsula and the establishment of their country there at the end of the seventh century $\mathrm{AD}^{2}$, the works of Nicephorus (before 758-828), the Patriarch of Constantinople in 806-815, author of Historía sýntomos, and Theophanes the Confessor $\left(?^{3}, 760-817\right)$, monk and author of Chronography, written in 810-814, are of primary importance to us ${ }^{4}$.
\end{abstract}

\footnotetext{
${ }^{1}$ A concise overview of the issue: L'écriture de la mémoire. La littératuré de l'historiographie, ed. P. Odorico, P. Agapitos, M. Hinterberger, Paris 2006 [= DByz, 6]; R. Scott, Text and Context in Byzantine Historiography, [in:] A Companion to Byzantium, ed. L. JAmes, Chichester 2010, p. 251-262; History as Literature in Byzantium. Papers from the Fortieth Spring Symposium of Byzantine Studies, University of Birmingham, April 2007, ed. R. Macrides, Aldershot 2010; M. Angold, M. Wiтнв,, Historiography, [in:] OHBS, p. 838-852.

${ }^{2}$ Recently on this subject: Г. АтАнасов, Кан Аспарух - едно ново начало, [in:] Българска национална история, vol. III, Първо българско изарство (680-1018), еd. Пл. ПАвлов, Велико Търново 2015, p. 13-67.

${ }^{3}$ Debate on the authorship of Chronography, traditionally attributed to the Confessor, continues - see the latest research results: TM 19, Studies in Theophanes, ed. M. Jankowiak, F. Montinaro, Paris 2015; A. KомPA, Gnesioi filoi: the Search for George Syncellus' and Theophanes the Confessor's Own Words, and the Authorship of Their Oeuvre, SCer 5, 2015, p. 155-230.

${ }^{4}$ More on Nicephorus and his Breviarium - P.J. Alexander, The Patriarch Nicephorus of Constantinople. Ecclesiastic Policy and Image Worship in Byzantine Empire, Oxford 1958; P. O'Connell, The Ecclesiology of St. Nicephorus I, Rome 1972; H.-G. BECK, Kirche und theologische Literature im byzantinischen Reich, München 1977, p. 489-491; H. Hunger, Die Hochsprachliche Profane Literatur der Byzantiner, vol. I, Philosophie - Rhetorik - Epistolographie - Gesschichtsschreibung - Geographie, München 1978, p. 344-347; Л.А. ФРЕйБеРг, Т. ПоповА, Византийская литература епохи разцвета IX-XV вв., Москва 1978, р. 48-52; И.С. Чичуров, Византийские исторические сочинения: Хронография Феофана, Бревиарий Никифора, Москва 1980, p. 145-150; J. KaraYannopulos, G. WeIss, Quellenkunde zur Geschichte von Byzanz (324-1453). Methodik. Typologie. Randzonen,
} 
Both accounts have already been often interpreted by generations of scholars, focusing, above all, on a number of fundamental research problems, namely: what was the number of people led by Khan Asparuh to the Danube, where and what was Oglos/Onglos mentioned in the texts, how many Slavic tribes actually lived in the territories conquered by Bulgarians south of that river, and what was the nature of the Bulgarian relations with local Slavs? ${ }^{5} \mathrm{I}$, on the other hand, will concentrate on issues that have either been omitted or barely examined by the majority of researchers. Thus, I am not so much interested in the reconstruction of events as in the opinion of Theophanes, author of Chronography, on the arrival of Bulgarians and their settlement in the former Byzantine territories on the Danube. In other words, I will propose an interpretation model of this Byzantine chronicler's text, an attempt to read the ideological message that I believe he deliberately included in his account.

For the sake of clarity, I will quote extensive excerpts from the texts by Theophanes and Nicephorus, albeit with a focus on the former.

vol. II, Wiesbaden 1982, p. 339-340; O. JuRewicz, Historia literatury bizantyńskiej. Zarys, Wrocław 1984, p. 135-137, 148-149; J. Travis, The Defense of the Faith. The Theology of Patriarch Nikephoros of Constantinople, Brookline 1984; A.P. KAZHDAN, Nikephoros I, [in:] ODB, vol. III, p. 1477; IDEM, L.F. Sherry, C. ANGelidi, A History of Byzantine Literature (650-850), Athens 1999, p. 211-215; L. Brubaker, J. Haldon, Byzantium in the Iconoclast Era (c. 680-850): the Sources. An Annotated Survey, Aldershot 2001, p. 171-172; Н. Сісноска, Nikefor, [in:] Encyklopedia kultury bizantyńskiej, ed. O. Jurewicz, Warszawa 2002, p. 370-371; V. VAVŘíneK, Encyklopedie Byzance, coop. P. BALCÁrKA, Praha 2011, p. 349; W. Treadgold, The Middle Byzantine Historians, New York-Basingstoke 2013, p. 26-31.

On Theophanes and his oeuvre - H. Hunger, Die Hochsprachliche Profane Literatur..., p. 334-339; И.С. Чичуров, Византийские исторические сочинения..., p. 17-23; J. KaraYannopulos, G. Weiss, Quellenkunde..., p. 338-339; O. Jurewicz, Historia..., p. 132-135; A.P. Kazhdan, Theophanes the Confessor, [in:] ODB, vol. III, p. 2063; I. Rochow, Byzanz im 8. Jahrhundert in der Sicht des Theophanes. Quellenkritisch-Historischer Kommentar zu den Jahren 715-813, Berlin 1991; A. Kazhdan, L.F. Sherry, C. Angelidi, A History ..., p. 205-235; L. Brubaker, J. Haldon, Byzantium..., p. 168-171; H. CichockA, Teofanes Wyznawca, [in:] Encyklopedia kultury..., p. 466-467; V. Vavř́́nek, Encyklopedie..., p. 481; W. Treadgold, The Middle Byzantine..., p. 38-77. In the case of both authors and their historical works, I include only selected monographs and dictionaries.

${ }^{5}$ There is vast literature on the subject. I am presenting only a selection of the most important overview works - W. Swoboda, Powstanie państwa bułgarskiego na tle słowiańskich procesów państwowotwórczych na Bałkanach, [in:] 1300-lecie państwa bułgarskiego 681-1981. Materiały z sesji naukowej, ed. T. Zdancewicz, Poznań 1983, p. 67-76; T. WASILEwsKI, Kontrowersje wokót powstania i najstarszych dziejów państwa bułgarskiego, [in:] Trzynaście wieków Bułgarii. Materiały polsko-bułgarskiej sesji naukowej, Warszawa 28-30 X 1981, ed. J. SiATKowski, Wrocław 1983, p. 181-189; Г.Г. ЛитАврин, К проблеме становления болгарского государства, [in:] IDEM, Византия и славяне (сборник статей), Санкт-Петербург 1999, р. 192-217. 


\section{Theophanes:}

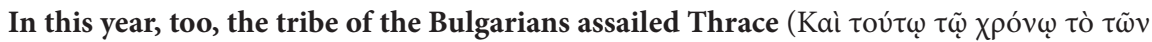

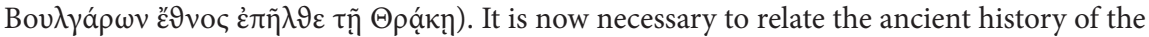
Ounnogoundour Bulgars and Kotragoi. On the northern, that is the far side of the Euxine Sea, is the so-called Maeotid Lake into which flows a huge river called Atel, which comes down from the Ocean through the land of the Sarmatians. The Atel is joined by the river Tanais, which also rises from the Iberian Gates that are in the mountains of Caucasus. From the confluence of the Tanais and the Atel (it is above the aforementioned Maeotid Lake that the Atel splits off) flows the river called Kouphis which discharges into the far end of the Pontic Sea near Nekropela, by the promontory called Ram's Head. From the aforesaid lake is a stretch of sea like a river which joins the Euxine through the land of the Cimmerian Bosphorus, in which river are caught the so-called mourzoulin and similar fish. Now on the eastern side of the lake that lies above, in the direction of Phanagouria and of the Jews that live there, march a great many tribes; whereas, starting from the same lake in the direction

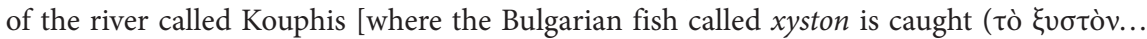

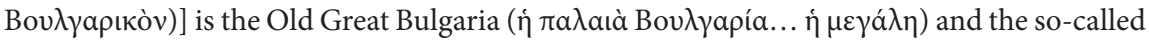
Kotragoi, who are of the same stock as the Bulgars.

In the days of Constantine, who dwelt in the West, Krobatos, the chieftain of the

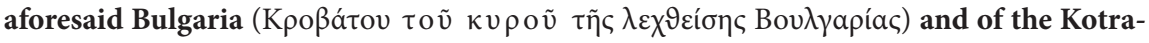
goi, died leaving five sons, on whom he enjoined not to depart under any circumstances from their common life that they might prevail in every way and not be enslaved by

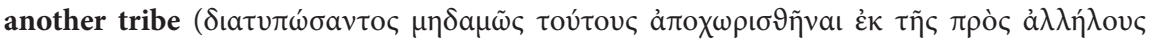

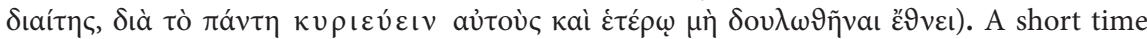
after his demise, however, his five sons fell out and parted company, each with the host

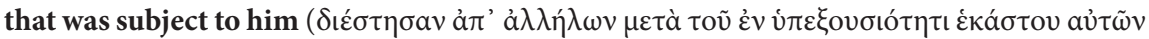

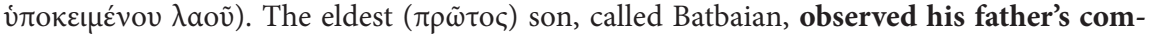

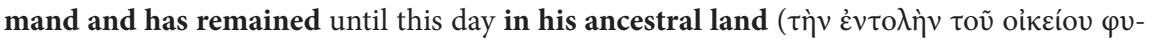

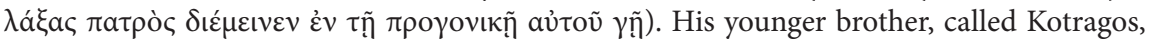
crossed the river Tanais and dwelt opposite his eldest brother. The fourth and fifth went over the river Istros, that is the Danube: the former became subject of the Chagan of the Avars

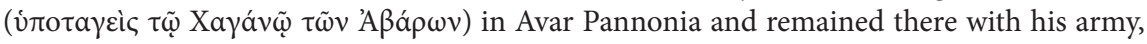
whereas the latter reached the Pentapolis, which is near Ravenna, and accepted allegiance to

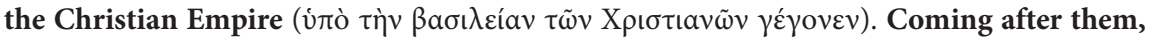

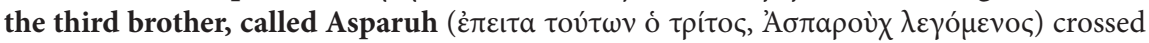
the Danapris and Danastris (rivers that are farther north than the Danube) and, on reaching the Oglos, settled between the former and the latter, since he judged that place to be secure and impregnable on both sides: on the near side it is marshy, while on the far side it is encircled by the rivers. It thus provided ample security from enemies to this tribe that had

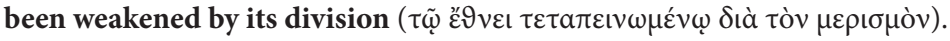

When they had thus divided into five parts and had been reduced to a paltry es-

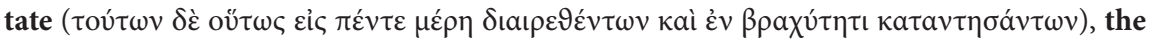
great nation of the Chazars issued forth from the inner depths of Berzilia, that is from the First Sarmatia, and conquered all the country beyond the sea as far as the Sea of Pontos; and they subjugated the eldest brother Batbaian, chieftain of the First Bulgaria, from

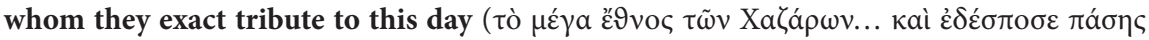

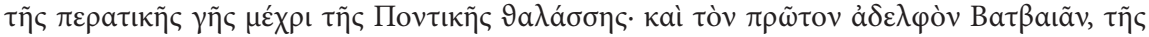

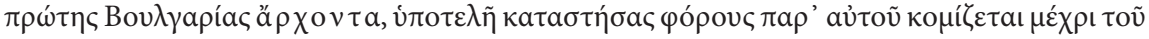


$v \tilde{v}$ ). Now, when the emperor Constantine had been informed that a foul and unclean tribe

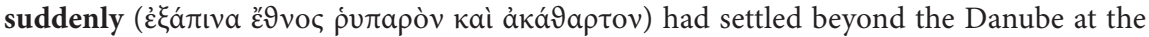
Oglos and was overrunning and laying waste the environs of the Danube, that is the country that is now in their possession, but was then in Christian hands ( $\tau 0 \tilde{v} \tau^{\prime}$ '

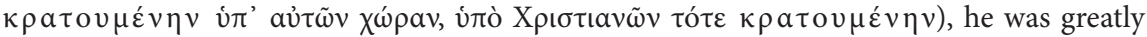
distressed and ordered all the themata to cross over to Thrace. He fitted out a fleet and moved against them by land and sea in an attempt to drive them away by force of arms, and he drew up his infantry on the land that faces the so-called Oglos and the Danube, while he anchored his ships by the adjoining shore. When the Bulgars had seen the sudden arrival of this enormous armament, they despaired of their safety and took refuge in the aforementioned

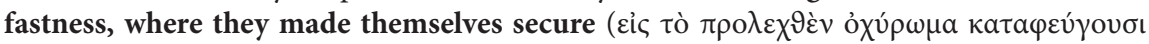

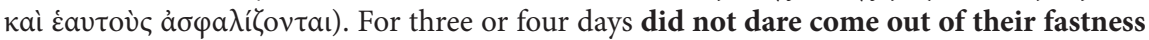

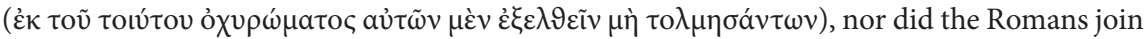
battle on account of the marshes that lay before them. Perceiving, therefore, the sluggishness

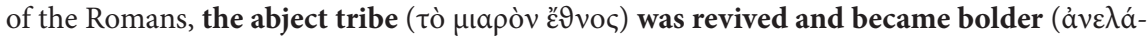

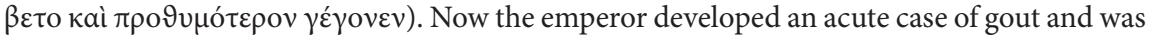
constrained to return to Mesembria together with five dromones and his retinue so as to have the use of a bath. He left behind the commanders and the army, whom he ordered to make simulated attacks so as to draw the Bulgars out of their fastness and so engage them in battle if they happened to come out, and if not, to besiege them and keep watch over the defences. But the cavalryman spread the rumour that the emperor was fleeing and, being seized by fear, they too, fled, although no one was pursuing them.

When the Bulgars saw this, they gave pursuit and put most of them to the sword and wounded many others. They chased them as far as the Danube, which they crossed and come to Varna, as it is called, near Odyssos and the inland territory that is there. They perceived that this place was very secure, being guarded at the rear by the river Danube, in front and on the sides by means of mountain passes and the Pontic Sea. Having, furthermore, subju-

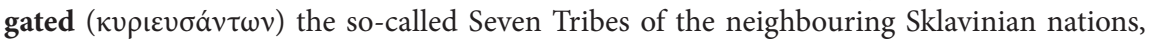
they settled the Severeis from the forward mountain pass of Beregaba in the direction of the east, and the remaining six tribes, which were tributary to them, in the southern and western regions as far as the land of the Avars. Having thus extended their domains, they grew ar-

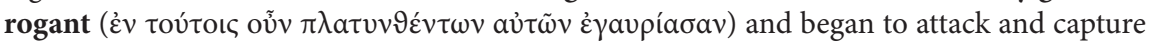
the forts and villages that belonged to the Roman state. Being under constraint, the emperor made peace with them and agreed to pay them yearly tribute. Thus the Romans were put to

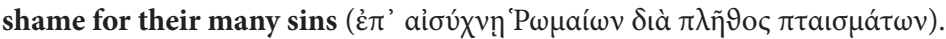

Both those who lived afar and those who lived near were astonished to hear that he who had subjugated everyone, those in the east and in the west, in the north and in the south,

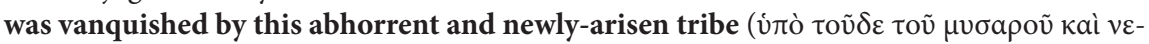

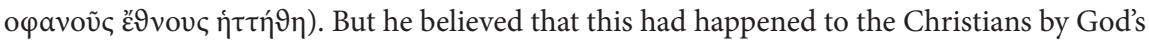
providence and made peace in the spirit of the Gospels; and until his death he remained undisturbed by all his enemies ${ }^{6}$ [emphasis mine - K.M.].

\footnotetext{
${ }^{6}$ Theophanis Chronographia, AM 6171, ed. C. DE Boor, vol. I, Lipsiae 1883 [= CSHB], p. 356, 18 - 359, 25; English translation: The Chronicle of Theophanes Confessor. Byzantine and Near Eastern History AD 284-813, trans. et ed. C. Mango, R. Scott, G. Greatrex, Oxford 1997, p. 497-499 (with minor changes by me - K.M.).
} 


\section{Nicephorus:}

It is now time to speak of the dominion of the Huns (as they are called) and the Bulgarians and their affairs. In the area of the Maeotic lake, by the river Kophis, lies Great Bulgaria (as it was called on olden times) and 〈here lived〉 the so-called Kotragoi, who are also of the same stock (as the Bulgarians). In the days of Constantine who died in the West, a certain man by the name of Kobratos became master of these tribes. On his death he left five sons, upon whom he enjoined not to part company under any circumstances, so that their dominion might be preserved thanks to their mutual friendship. But they took little account of the paternal injunction and a short time thereafter they divided, each one of them taking his own share of their people. The eldest son, called Baianos, in accordance with his father's command, has remained until this day in his ancestral land. The second, called Kotragos, crossed the river Tanais and dwelt opposite the first; the fourth went over the river Istros and settled in Pannonia, which is now under the Avars, becoming an ally of the local nation. The fifth established himself in the Pentapolis of Ravenna and became tributary to the Romans. The remaining brother, called Asparuh, crossed the rivers Danapris and Danastris and settled near the Istros, where he found a suitable place for habitation (called Onglos in their language), which happened to be difficult 〈of access〉 and impregnable by the foe: for it is secure in front because it is impassable and marshy, while at the back it is fenced by inaccessible cliffs. When this nation had thus divided and scattered, the tribe of the Chazars, 〈issuing) from the interior of the country called Bersilia, where they had lived next to the Sarmatians, invaded with great audacity all the places that are beyond the Euxine Sea. Among others, they subjected Baianos to paying tribute them.

When Constantine became aware that the nation which had settled by the Istros was attempting to devastate by its incursions the neighboring places that were under Roman rule, he conveyed an army to Thrace and, furthermore, fitted out a fleet and set out to ward off that nation. On seeing the multitude of cavalry and ships and amazed as they were by the unexpected suddenness 〈of the attack $\rangle$, the Bulgarians fled to their fortifications and remained four days there. Since, however, the Romans were unable to engage them in battle because of the difficulty of the terrain, they regained strength and eagerness. Now the emperor was seized by an attack of gout and being in much pain, sailed off to the city of Mesembria for treatment after giving orders to the officers and soldiers to keep on investing the fort and do whatever was necessary to oppose the nation. But a rumor spread about that the emperor had fled and, being on this account thrown into confusion, they fled headlong although no one was on their heels. Seeing this, the Bulgarians pursued them in strength, killing those they caught and wounding many others. After crossing the Istros in the direction of Varna, which is near Odyssos, and perceiving how strong and secure was the inland area thanks to the river and the great difficulty of the terrain, they settled there. Furthermore, they subjugated the neighboring Slavonic tribes, some of which they directed to guard the area in the vicinity of the Avars and others to watch the Roman border. So, fortifying themselves and gaining in strength, they attempted to lay waste the villages and towns of Thrace. Seeing this, the emperor was obliged to treat with them and pay them tribute [emphasis mine - K.M.]. ${ }^{7}$

\footnotetext{
${ }^{7}$ Nicephori Patriarchae Constantinopolitani breviarium historicum, 35-36, ed. C. MANGo, Washingtoniae $1990[=C F H B]$ (cetera: NicEPHORUs), p. 86, 38 - 90, 29; English translation: ibidem, p. 87-91 (with minor changes by me - K.M.).
} 
At first glance, two basic conclusions can be drawn from the two texts. First of all, both descriptions are almost identical, which clearly indicates that their authors used a common historical source with regard to the discussed subject ${ }^{8}$. Secondly, Nicephorus conveys the information dispassionately, while Theophanes' account is definitely more emotional and personal, as it is enriched by additional epithets that were most likely absent from the original description. The latter observation allows us to assume that the creation of the past in the text by the Byzantine chronicler is much more conscious and deliberate, i.e. he imbued it with a deeper meaning, offering his own interpretation of the account of an anonymous predecessor, whose text he used to recreate the original Bulgarian history in the Balkans. Under these circumstances, Nicephorus' message seems to be more of a point of reference for Theophanes' text, highlighting the content that the latter added to the text of their shared source, which undoubtedly lent a unique depth to the account of the arrival of Bulgarians on the Lower Danube. On the other hand, we must not forget that most of the ideas in Theophanes' message probably came directly from the author of the older text, which served as the basis for the accounts by the two Byzantine authors. In any case, a meticulous comparative analysis of the language and content of both texts carried out by Vesselin Beševliev proves the precedence of Theophanes' story over that by Nicephorus. It follows that the former held closer to the original message from the eighth century, while the latter abbreviated it, omitting certain phrases. This does not mean that Theophanes never skipped fragments of the original narrative either. However, the eminent Bulgarian philologist and historian concluded that regarding the events described, Nicephorus loses his position as the main source and must be seen as an auxiliary text for a better understanding of Theophanes' message, as a skillful paraphrase of their shared primary account ${ }^{9}$. However, this statement does not alter the fact that the discrepancies are not so substantial as to rule out the significance of Nicephorus' text for the control of Bulgarian passages in Theophanes' case. Even more so, we know that the latter sometimes intentionally passed over information known from elsewhere in the description of the future patriarch ${ }^{10}$. As I have already pointed out above, even in the excerpts from both works cited above it is evident that the Confessor used a number of epithets addressed to Bulgarians that are absent in Nicephorus' works, which clearly proves the chronicler's

\footnotetext{
${ }^{8}$ This obvious fact has already been pointed out - cf. е.g. В. Бешевлиев, Съобщението на Теофан за основаването на българската държава, ИНМВ 18 (33), 1982, p. 34; С. MANGO, Introduction, [in:] NiCEPHORUS, p. 15-16.

${ }^{9}$ В. БЕшевлиЕв, Съобщението..., p. 34-39; С. MANGo, Introduction..., p. 16.

${ }^{10}$ These include the omission of the fact that Emperor Justinian II Rhinotmetos (685-695, 705-711) granted the Bulgarian Tervel the title of caesar in 705, a piece of information taken from the same source as the story of Bulgarians migrating to the Danube. More on this vide M.J. LESzKA, Wizerunek władców Pierwszego Państwa Bułgarskiego w bizantyńskich źródłach pisanych (VIII - pierwsza połowa XII wieku), Łódź 2003 [= BL, 7], p. 20-23.
} 
own invention in this respect, going beyond the content of the original account. The deliberate interference in the description of events is also evidenced by the fact that, when constructing the story of former Bulgarian settlements from before their arrival on the Lower Danube, he included in his narrative information from sources other than the text by the anonymous author from the first quarter of the eighth century ${ }^{11}$.

Scholarly literature points out that neither Theophanes nor Nicephorus devotes almost any attention to the characteristics of Asparuh. Morover, it has been indicated that they ignore his role in the events associated with the founding of the Bulgarian Danube State. It is believed that this was due to the lack of information or a deliberate omission of the source used by both chroniclers ${ }^{12}$. At other times, it is believed that this was the result of the mechanical inclusion of a separate source, specifically dedicated to the campaign of Emperor Constantine IV Pogonatos (668-685) against the Bulgarians in the Danube Delta. The latter view, although probable, is not conclusive ${ }^{13}$.

Although the above conclusions on the portrayal of the first Khan of the Danube Bulgaria are generally correct, it seems to me that one could be tempted to draw a little more data from the accounts by both Byzantine historians. The legend of Kubrat (Krobatos, Kobratos of the sources) ${ }^{14}$, already mentioned by Theophanes (and Nicephorus, of course), who on his deathbed orders his sons to remain united and not to divide the state, implicitly includes the characteristics of Asparuh and his brothers. Kubrat, Lord (Gr. кúpıoৎ) of the Great Bulgaria, is presented here as a prudent man who cared about the safety of his people and wanted to prevent the disintegration of his country. In this context, the reference to his five sons, including Asparuh, being in conflict with one another testifies to their immaturity, arrogant nature and desire for power. Everyone wanted to be independent, they did not want to share power and consult one another. The Byzantine chronicler states that their division brought about the one thing that Kubrat was trying to counteract, namely the fall of the First Bulgaria. And so the descendants of the Khan - old and therefore more experienced and wise

\footnotetext{
${ }^{11}$ Vide philological analysis in В. Бешевлиев, Съобщението..., p. 34-35. Warren Treadgold, The Middle Byzantine..., p. 8-17, assumes that the author of this lost historical work was Trajan the Patrician, who lived and worked during the reign of Emperor Justinian II.

${ }^{12}$ M.J. LeszKa, Wizerunek..., p. 13, 32-34. On Asparuh vide e.g. В. Гюзвлев, Ал. Фол, Хан Аспарух, [in:] Бележити българи, vol. I, 681-1396, ed. Б. ЧолпАнов, В. ГюзЕлев, София 1967, p. 7-25; V. GuUzelev, Chan Asparuch und die Gründung des bulgarischen Reiches, [in:] MBu, vol. III, p. 25-46; Й. АндРеЕв, М. ЛАлков, Исторически справочник. Българските ханове и иаре. От хан Кубрат до ияар Борис III, Велико Търново 1996, p. 16-21; Й. АНДРеЕв, Аспарух, [in:] IDEм, Ив. ЛАЗАРов, Пл. ПАвлов, Кой кой в в Средновековна България (Трето допвлнено и основно преработено издание), София 2012, р. 54-59; Г. АтАнАсов, Първосторителите на българската държавност. Органа, Кубрат, Аспарух, Тервел, София 2015, р. 161-246.

${ }^{13}$ В. Бешевлиев, Съобщението..., р. 49.

${ }^{14}$ Г. АтАнасов, Първосторителите..., p. 47-160.
} 
- disregarded and betrayed the last will of their own father. Thus, they did not show him respect as their parent, which for every Christian, and especially for a monk like Theophanes, must have been on a par with a violation of one of the Ten Commandments, one that directly follows those concerning man's attitude towards God himself, and thus the most important in terms of family relations, and in the long run also social relations, and in the case of the ruling family, as we will see, even interstate relations:

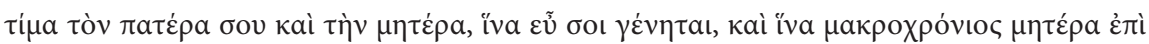

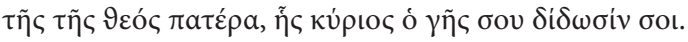

Honor your father and mother as that it may be well with you and so that you may be longlived on the good land that the Lord your God is giving you ${ }^{15}$.

Let us start with the most obvious thing, namely that we are dealing with God's commandment here, and although Kubrat's sons were neither followers of Judaism nor Christians, for Theophanes and his readership the commandment applied to all people, regardless of their knowledge of the matter. Since it concerned one of the most important requirements that Lord gave unto his creation, this fact alone was enough to obey this command. This order to honor one's parents, repeated once again literally in the Deuteronomy ${ }^{16}$, which undoubtedly also included obedient and faithful observance of their recommendations, entailed, as St. Paul emphatically states in his Letter to the Ephesians ${ }^{17}$, a promise, we would say a specific justification and an incentive for such an attitude towards one's parents. Respect for them and the principles they instilled guaranteed success and a long, peaceful life in the territories that God bestowed on individual persons/ peoples $^{18}$. The Apostle himself pointed out in the aforementioned letter that the

${ }^{15}$ Exodus, 20, 12, [in:] Septuaginta. Id est Vetus Testamentum graece iuxta LXX interpretes, vol. I, ed. A. Rahlfs, rec. R. Hanhart, Stuttgart 2006, p. 120; English translation - Exodus, trans. L.J. PerKins, [in:] A New English Translation of the Septuagint, ed. A. Pietersma, B.G. Wright, Oxford 2007, p. 65.

${ }^{16}$ Deuteronomium, 5, 16, [in:] Septuaginta..., vol. I, p. 296.

${ }^{17}$ Ad Ephesios, 6, 1-3, [in:] Novum Testamentum Graece, ed. B. Aland, K. Aland, J. KaravidopouLos, C.M. Martini, B.M. Metzger, ${ }^{28}$ Stuttgart 2012, p. 601; English translation - The Pocket Interlinear New Testament. Numerically Coded to Strong's Exhaustive Concordance, ed. J.P. GREen, Grand Rapids 1988, p. 529: Children, obey your parents in the Lord, for this is right. Honor your father and mother, which is the first commandment with a promise, that is may be well with you, and you may be

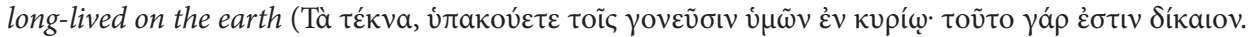

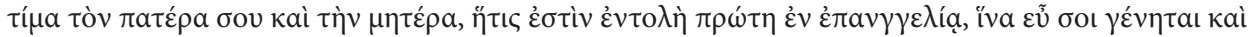

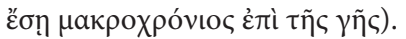

${ }^{18}$ Cf. Actus Apostolorum, 17, 26, [in:] Novum Testamentum Graece..., p. 442; English translation: The Pocket Interlinear New Testament..., p. 377: And He [i.e. the God - K.M.] made every nation of men of one blood, to live on all the face of the earth, ordaining fore-appointed seasons and boundaries of their 
Old Testament commandment and the ensuing promise are directly related to the issue of obedience to one's parents. As we can see, therefore, it is a promise that perfectly corresponds to the instruction that Kubrat left to his male descendants - if they remain faithful to his commandment, they will live and reign over the land of their ancestors, which he entrusted to their care. The development of the idea of honoring one' parents, and specifically obedience to the teachings of the father and the blessing associated with it, can be found in the Book of Proverbs:

\author{
Listen, children, to a father's discipline

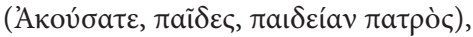 \\ and pay attention, that you may come to \\ know-how insight, \\ for I present to you a good gift; \\ do not abandon my law \\ ( \\ For I became a son, and I am obedient to \\ we father

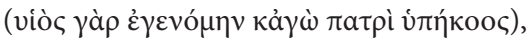 \\ and beloved in the eyes of my mother, \\ who would speak and instruct me: \\ "Let our word become fixed in your heart. \\ Keep the commandments; do not forget \\ nor disregard the sayings of my mouth

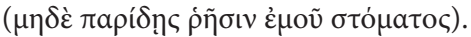 \\ Nor abandon her, and she will cleave to you; \\ love her, and she will guard you; \\ Secure her, and she will exalt you; \\ honor her, that she may embrace you \\ in order that she may grant your head a \\ garland of graces \\ and may protect you with a garland \\ of delight". ${ }^{19}$
}

The text makes it clear that the father's instruction is a gift for his children, the culmination of the wisdom of his life, through which he wants to ensure that his descendants are successful. This commandment is intended to protect, exalt, shield, and grant them various graces. To give strength and security, to be a testimony of their noble character, because they respect the words of the one who sired them, and to guarantee power and victory, as the reference to the wreath indicates.

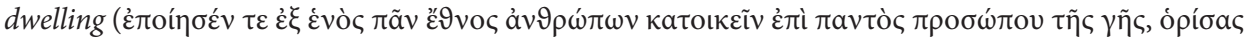

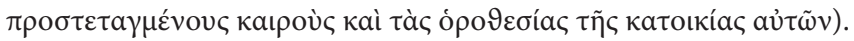

${ }^{19}$ Proverbia, 4, 1-9, [in:] Septuaginta..., vol. II, p. 188-189; English translation: Proverbs, trans. L.J. Perkins, [in:] A New English Translation..., p. 626. Cf. also Prv 1, 8-9; 6, 20-22; 13, 1; 23, 22-25 (Septuaginta..., vol. II, p. 183, 193, 204, 222). 
Therefore these are exactly the things that the old Bulgarians' Khan sought for his sons. The biblical father strongly emphasizes that his words should not be disregarded, and the text repeats the instruction that the offspring should not deviate from his commandments and customs. In order to reinforce the message, he adds that he followed his own parents' instructions faithfully, and it was that very custom of obedience that he did not want his successors to abandon. The offspring are not only responsible to their father, but also to all previous generations, to their ancestors, who bore the burden of responsibility for their shared heritage before them. This idea is amplified by the father's reference not to his own words, but to the warnings addressed to him by his parents. A similar element is also to be found in Theophanes' account, who indicated that Kubrat implored his sons not to abandon their current customs, as well as emphasized that only Batbaian (Baianos, i.e. Baian), guarding the father's will, remained on the land of his ancestors. He was therefore the only one to respect tradition and not to betray the will of his forefathers.

Also the ancient Greek thought, in one way or another living and cultivated in the Eastern Roman Empire, regarded respect for parents as one of the cardinal, unwritten natural laws, and its violation as an expression of ungodliness ( $\delta v \sigma \sigma \varepsilon \dot{\beta} \varepsilon ı \alpha)$. When the suffering Heracles gave the last orders to his son Hyllus on his death bed (i.e. in the same situation as Kubrat) - to help him die and marry Iole, his beloved captive, after his passing - and Hyllus did not want to fulfill them, the hero said:

Since, then, my son, those words are clearly finding their fulfilment, thou, on thy part, must lend me thine aid. Thou must not delay, and so provoke me to bitter speech: thou must consent and help with a good grace, as one who hath learned that best of laws, obedience to a sire ( vó

[...]

Even so. This, in brief, is the charge that I give thee, my son. When I am dead, if thou wouldest show a pious ( $\varepsilon \dot{v} \sigma \varepsilon \beta \varepsilon \tau v)$ remembrance of thine oath unto thy father, disobey me not ( $\mu \eta \delta^{\prime}$

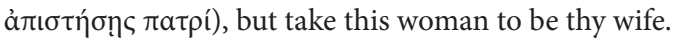

Hyllus faced the threat of vengeance from the gods for his disobedience, as Heracles invoked:

He [i.e. Hyllus - K.M.] will render no reverence, it seems, to my dying prayer--Nay, be sure

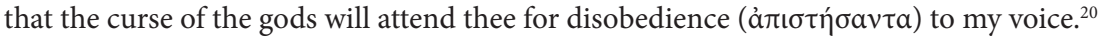

Here, as in biblical tradition, we have a reference to vó $\mu$ oc, a law or a custom that dictates that sons listen to their fathers even if they do not agree with their instructions. In addition, however, unpleasant consequences are pointed out

${ }^{20}$ Tpaxivıal, [in:] Sophoclis tragoediae, vol. II, Trachiniae, Antigone, Philoctetus, Oedipus Coloneus, ed. R.D. DAwE, Leipzig 1985 [= BSGR], p. 42, 1174-1178; p. 43, 1221-1224; p. 44, 1238-1240; English trans. - Trachiniae, [in:] The Tragedies of Sophocles, trans. R.C. Jевв, Cambridge 1917, p. 319, 321. 
- the curse of the gods - which will surely affect the progeny that refuses to obey the parents. This element is evident in the fate of most of the descendants of the Old Bulgaria's rulers.

Regardless of which tradition we rely on, or even of their coalescence, disobeying their father's orders put Kubrat's sons in a negative light in the eyes of the reader, and a further description of the events confirmed that such an attitude was disastrous. The division and dispersion of the people led to the weakening of each individual part of the thereof, as a result of which three of the brothers (the fourth, the fifth and the eldest Batbaian), together with their subjects, fell under the dominion of foreign rulers. Thus they lost the legacy of their ancestors, namely independence (including power) and freedom. By rejecting unity and mutual benevolence, they wasted the achievements of previous generations, that is everything what their predecessors had toil over and to which their father had devoted his life. Admittedly, the two brothers managed to keep their freedom and acquire new territories for themselves, but in the case of Kotrag this was probably because he took over the areas further north of the busy Black Sea routes, thus avoiding the fate of Batbaian. Moreover, from the Byzantine point of view, he did not threaten the empire in any way, so his transgression was a bit less severe. As for Asparuh, his success, in the light of our source, was not so much the result of his own skill and merit, or that of his people, but the effect of the mistakes of the Byzantines themselves.

According to the text, the only righteous and obedient son of Kubrat was Baian, the only one that Theophanes calls the chiftain (Gr. ä $\rho \chi \omega v$ ) of the First Bulgaria. It seems that, according to the Byzantine chronicler, he alone deserved to bear this title and to be the head of all Bulgarians. First of all, he was the eldest ${ }^{21}$. Secondly, while he was also at odds with his brothers, he was the only one to observe his father's command, as he wanted to stay on the land of his ancestors in order to keep the legacy he had inherited. Thus, he fully deserved the title of ruler, just like his father, for he showed wisdom, as befitted the eldest of the family. Theophanes presents him as a positive hero of his tale. He proved his respect for his parent by

\footnotetext{
${ }^{21}$ I feel obliged to indicate that according to Ivan Venediкov (Митове на българската земя, vol. I, Медното гумно (Второ преработено издание), Стара Загора 1995, p. 41-42) the sons of Kubrat of Theophanes' account were not ranked according to seniority, but according to the order in which they occupied the geographical areas indicated. This is a thoroughly justified view, which I would consider convincing, albeit with the exception of Baian, who seems, in the light of our source, to have had the strongest claim to the original territory of his father, or more precisely to the supreme authority over it, most probably because of his age. It cannot be ruled out that it was for this very reason that he was the only one to be called ruler by Theophanes. Despite this, the probability that the sons of Bulgarian Khan were listed in the order of seniority remains strong - it can be indirectly proved by a comparison in the source of the first and old Bulgaria (Kubrat's) with that of Asparuh, treated as second and new, and then in Theophanes' narrative clearly called Bulgaria. In other words, for the Byzantine chronographer the first one was equal to the old one, which could also apply to the sons of the old ruler - the first of them was the oldest, etc.
} 
keeping his commandment. The chronicler, however, does not want to emphasize the very idea of obedience to his father. This obedience has a much deeper, very specific meaning for him. Through it, Baian stayed in his place, in the land that the Byzantines accepted as a territory that belonged to Bulgarians ${ }^{22}$. I have no doubt that Theophanes believed and suggested that it was there, on the banks of the Kouphis River and the Maeotid (Meotic in Nicephorus) Lake, that they were allowed to be rulers and masters, and that even a local species of fish could be called Bulgarian there. Moreover, the fact that this fish is referred to as such is an indication of the how long the Bulgarians inhabited the area. These are the territories of the First, Ancient/Old and Great Bulgaria. The only true Bulgaria! Great

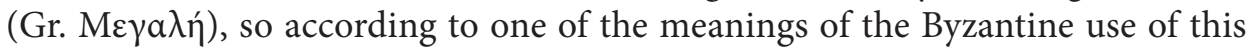
Greek term - Further or Remote $e^{23}$, and therefore not in the immediate vicinity of

${ }^{22}$ And if we take into account the testimony of Patriarch Nicephorus, it was also the territory in which they functioned as allies of Byzantium, fulfilling their obligations towards the empire, enjoying the favor and friendship of the Constantinople rulers - Nicepнorus, 22, p. 70, 1-7; В. БЕшевлиЕв,

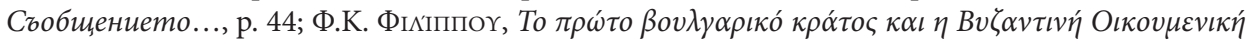

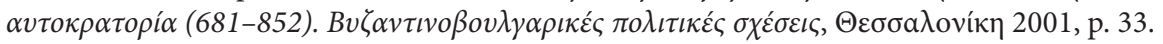

${ }^{23}$ Cf. R. Dostálová, МЕГА НН MOРАВIA, Bsl 27, 1966, p. 344-349; И.С. ЧИчуров. Византийские исторические сочинения..., p. 110, an. 264; TNDS.SG, vol. III, p. 91, an. 29. Vide also V. VAcнкоva, Danube Bulgaria and Khazaria as Parts of Byzantine Oikumene, [in:] The Other Europe in the Middle Ages. Avars, Bulgars, Khazars and Cumans, ed. F. Curta, R. Kovalev, Leiden 2008, p. 345, according to which Old Great Bulgaria means peripheral (by analogy with the Scythia Minor/Scythia Maior and Asia Minor/Asia Maior), which is not part of the main body of the Byzantine world, in other words barbaric, unlike Asparuh's Minor, or civilized, Romanized Bulgaria. It should be stressed that in fact the peripheral Bulgaria stands semantically close to the remote one, from the point of view of the center, i.e. Constantinople. Of course, Kubrat's state was barbaric for the Romans, but those barbarians distant from the essential Byzantine territories were better barbarians than those who forcibly occupied the imperial lands! In addition, Theophanes was not at all positively disposed towards civilized and Romanized Bulgarians and their Danube Khanate, as evidenced not only by an in-depth analysis of the passus on Asparuh's migration, but also by the rest of his text on Bulgarian issues. Therefore, the second part of the above statement can only be accepted if we apply it exclusively to the geographical area - outside and within the Roman borders - and not to Asparuh's Bulgaria as such. There is also another view (О.Н. Трувачев, Этногенез и культура древнейших славян. Лингвистические исследования, ${ }^{2}$ Москва 2003, p. 261-265) on the meaning of the Greek term $\mu \varepsilon \gamma \alpha \lambda$ í combined with a national or, more generally, a territorial name, according to which,

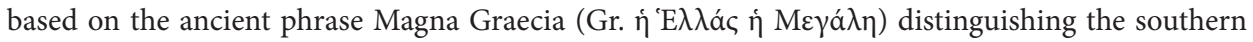
parts of the Apennine Peninsula and Sicily, later inhabited by Greek colonists, in contrast to the areas where they originally resided, as well as referring to later examples such as Britain-Great Britain, Scotia Minor-Scotia Maior and Малороссия-Великороссия, it can be concluded that this term meant only new, newly or afterward occupied/acquired territory. In this sense, according to the Russian linguist, Great Moravia was different from the original Moravia, and the word great pointed to the direction of the migration process from the original areas of residence. Trubachov's comments are undoubtedly important, but I would not be as categorical as he is in stating that the Greek word $\mu \varepsilon \gamma a \lambda \dot{n}$ can only be understood in the way he has indicated. Without going deeper into the topic, let me just point out that another example, built on the same principle as the one he cites, raises justified doubts - namely Scythia Minor-Scythia (Maior/Magna), because we cannot assume that it would 
the core territories of the Byzantine state, as the present Closer and Second, Danube Bulgaria ${ }^{24}$. In other words, one that threatened neither the Byzantine capital

mean the migration of ancient Scythians from today's Dobrudzha towards their settlement on the northern shores of the Black Sea. Another doubtful example is the fact that as early as in the Middle Ages, the former Magyar ancestral land on the Volga River, from which they emigrated to Central Europe, used to be known as Ungaria Maior/Magna, and not, as one would expect according to Trubachov's rationale, as Ungaria Minor! However, I am not going to discuss this issue further because for me it is more important that the Russian linguist's idea has been approved by other scholars with respect to Kubrat's Great Bulgaria - see, e.g. Цв. СтепАнов, О локализации "Великой Болгарии" Кубрата, BHR 24.2, 1995, р. 8; Ст. ЙордАнов, За социално-политическата организация на Кубратова Велика България: I. Племенната общност на уногундурите, Patria Onoguria и Beлика България, [in:] БСП, vol. V, p. 63-64. And as the latter scholar claims: either Great Bulgaria as a whole is a newly conquered territory, or part of Kubrat's state was described as such - a kind of 'terminus technicus' to designate the acquired territories that did not belong to the original tribal territory of Bulgarians. As I have already pointed out, such an interpretation of the term great is fully plausible, even though we cannot treat it as the only valid one. Without fully rejecting this view, because unlike the indicated researchers I am not looking for what is real in Theophanes, but rather for what is imagined (or rather his reading of the source text on which he based his account), I must stress that in the case of the Byzantine chronicler (as well as his source) matters are much more concrete than in that of Great Moravia, on which the scholars base their conclusions. This is because in the Byzantine narrative other adjectives, such as the old/ancient ( $\dot{\eta} \pi \alpha \lambda \alpha$ เó) and the first ( $\dot{\eta} \pi \rho \dot{\omega} \tau \eta)$ were used to denote Kubrat's Bulgaria - the first in connection with the aforementioned great, and the second directly as a substitute or synonym for the last one! From the context of the entire description devoted to the creation of the Danube Khanate, it follows that to write about Old, Great and First Bulgaria, the anonymous author of the base text, as well as Theophanes, did not mean it as a newly conquered area (because they would then contradict themselves, claiming that it is old, or better ancient, as well as first) but on the contrary, they considered it as primary Bulgarian territory. This is because by mentioning it, they were actually concentrating on the Danube Bulgaria, which from their point of view was a newly conquered, secondary land occupied by Asparuh's Bulgarians. This is also evidenced by the term used by Theophanes to designate the original areas inhabited by the Chazars, namely Berzilia in First Sarmatia, from which they migrated to other territories as a result of the division between the sons of Kubrat. So in both cases - Bulgaria and Sarmatia - first meant original to our authors and it does not matter for me here whether or not they erred in their views on this subject from the point of view of modern historical scholarship. Because according to Trubachov's logic (Moravia - Great Moravia) there should be some kind of Bulgaria before the Great Bulgaria, and even if there was one, Theophanes did not mention it. In other words, as he explicitly writes, Kubrat's Bulgaria was the original one for him. On the other hand, even if I accept the interpretation that Byzantine authors were really aware [either by mechanically copying from earlier sources, or by in some other way (?) assimilating the adjective $\mu \varepsilon \gamma \alpha \lambda$ ń to denote Kubrat's early state] that part of the territory of Kubrat's state (and why not its entire area?) was newly acquired, they still considered Great Bulgaria as the old and original with regard to Danube Bulgaria. In any case, there is no doubt that in his description Theophanes focuses more on the juxtaposition between Kubrat's Bulgaria and that of Asparuh than on the internal relations between individual areas of the former. Which, by the way, did not mean that there were not any.

${ }^{24}$ More on the so-called Old Great Bulgaria cf. e.g. Г. АтАнасов, Старата Велика България и кан Кубрат, [in:] Българска национална история, vol. II, Древните българи, Старата Велика България и нейните наследници в Източна Европа през Средновековието, еd. Пл. ПАвлов, Велико Търново 2013, p. 107-170; Р. РАшев, Културата на Старата Велика България - археологиче- 
nor its hinterland. In yet another sense of this Greek term the Old and Great Bulgaria is opposed, as undivided one, to the New and Minor Danube Bulgaria ${ }^{25}$. New, because devoid of roots and tradition, not yet having any justified claim over the newly occupied territories, in contrast to the ancient, i.e. rooted, longestablished, imbued with the tradition of Bulgarian tribes, with real and indisputable rights to its land. Minor because it was formed only by a part of the people who made up this old, great, that is to say, powerful one, probably covering also vast territories by default. The Byzantine text indicates that while the power and security of Great Bulgaria was to be determined by the unity of thought and action of the sons of Khan, and therefore the large number of their subjects taken together, the defense and peace of that part of the people who emigrated along with Asparuh were to be decided by the natural environment between Oglos, and the Dnieper and the Dniester. The divided nation could no longer rely on its own strength, which would undoubtedly have added to its glory ${ }^{26}$. However, no matter how we understand the meaning of Great Bulgaria, there can be no doubt that for Theophanes it was precisely there, in this distant northern land, that both Baian and all other sons of Kubrat, should remain in order to jointly rule the lands of their forefathers. Their obedience and fidelity to the orders of their parents were to guarantee not only their own prosperity, but also, indirectly, the peace of the empire itself - the existing status quo.

The rebellion of the four brothers undermined the authority of the eldest Baian, whose opinion they should, after all, consider. Not only did they ignore their father's instructions, but they neglected to show respect for the one among them who most deserved it. Their schism led to brought misfortune on him - innocent, because he heeded his father's warning. Weakened, left to his own devices, he had no chance of confronting the Chazars and had to recognize their sovereignty - in the source text, his tribe that had been weakened by its division and reduced to a paltry estate, is clearly contrasted with the great nation of the Chazars, to which the former had

ски паметници, [in:] Българска национална..., vol. II, p. 171-248; Н. Хрисимов, Българската държавност и Старата родина (VII-XI в.): така наречената Черна България, [in:] Бблгарска национална..., vol. II, p. 249-296.

${ }^{25}$ Cf. M. Betti, The Making of Christian Moravia (858-882). Papal Power and Political Reality, Leiden-Boston 2014, p. 15, an. 17.

${ }^{26}$ Veselin Beševliev (Съобщението..., p. 47-48) sees a misunderstanding in Theophanes' text because in the light of his own account, as well as that of Nicephorus, Asparuh set off only with one part of Bulgarians and not with the entire nation, so the scholar is surprised by the Byzantine chronicler's statement that Oglos offered shelter to a nation diminished in number because of the division. Adopting the interpretation I proposed above, this contradiction should not come as a surprise, as it is in line with the logic of the Byzantine author's account and proves that Theophanes still referred here to the unfortunate division of Bulgarians as a result of disobeying Khan Kubrat's instruction. For him, the nation was a community of Bulgarian tribes living in unity in the territory of Old Bulgaria, so Asparuh led only a part of it, which was by necessity weakened and therefore in need of safe shelter. 
to succumb. It is worth noting that, in the light of the Byzantine author's testimony, the Chazars left their ancestral land, namely Berzilia, which was the innermost region of First Sarmatia, only when the Bulgarians became conflicted and their state lost power (Nicephorus adds that upon learning that the new invaders grew arrogant). Such a narrative implies that if Kubrat's descendants had followed his orders, a new important political factor in the region, namely the Chazars, would not have appeared. Moreover, the fact that his younger brothers took little account of the paternal injunction also brought misfortune upon Byzantium, as Asparuh, having abandoned the former territories, settled down with his part of the people on the lower Danube and began to plunder the territories that belonged to the empire. Meanwhile he should have stayed in the country of his ancestors, enjoy the peace and power in the land he owned, and enjoy catching xyston fish. He should respect his father's will and, like his eldest brother, prove to be his faithful steward. His disobedience, arrogance and lust for power, which are all grave sins, led to problems in the empire itself - unfaithfulness to his father's will led not only to the fall of the First, Old and Great Bulgaria, but also brought misfortune on the innocent Eastern Rome! In other words, in global terms, the disobedience of the sons of the Bulgarian Khan not only brought misery on most of them, but also led to the violation of the existing geopolitical order in this part of the world - the collapse of Bulgaria, Chazars expansion and the loss of part of the Byzantium's territory.

This, in my opinion, is, among other things, the message of a story about the origins of Bulgarians. Its aim was to explain how they came be in the Danube region, according to Theophanes, who relayed the words of the eighth century author, in a country that is now in their possession, i.e. perhaps circa 720 in the original narrative ${ }^{27}$, but, as the Confessor understood it, undoubtedly referring also to the second decade of the ninth century, when he wrote his work. Of course, the entire description of the origins of the Bulgarian tribes is also an ethnographic excursion, typical of Greek literature since Herodotus, included in historical works in order to familiarize readers with the history and customs of the people who appeared on the historical arena at a given moment and made themselves part of the history of the Greeks, and in this particular situation - of the Byzantines ${ }^{28}$.

The account of the occupation of the new homeland by Asparuh's Bulgarians leaves no doubt as to the views of its author. This people were in the same situation

\footnotetext{
${ }^{27}$ The fact that this phrase was in the original source and referred to the time when it was written was pointed out by В. Бешевлиев, Съобщението..., p. 37; cf. p. 34, 46 (due to a similar wording referring to Batbaian's stay in the area of the so-called First Bulgaria). Cyril MANGo (Introduction, [in:] Nicephorus, p. 15-16; this is accepted by W. Treadgold, The Middle Byzantine..., p. 8, 12, 17), suggests that this work, shared by Theophanes and Nicephorus, was written circa 720 .

${ }^{28}$ Cf. B.A. Todorov, Byzantine Myths of Origins and Their Functions, SSBP 2, 2008, p. 66-67; A. KAldellis, Ethnography after Antiquity. Foreign Lands and Peoples in Byzantine Literature, Philadelphia 2013, p. 93-98.
} 
as their countrymen under the authority of the other sons of Kubrat, i.e. they were also weakened by the division and unable to confront a more serious opponent. This is evidenced by the description of the Byzantine campaign against Oglos - upon seeing the imperial forces, Bulgarians doubted that they could survive and the only thing they could do was to hide behind the walls of the fortifications mentioned in the text and the vast mudslides. The author explicitly states that they did not have the courage to face the Byzantine forces in an open field. In other words, all the advantages were on the Byzantine side. It was therefore necessary, in accordance with the order of the emperor, who had to go to Mesembria for treatment, to trick opponents out of the fortifications and forcing them to fight an open battle. Or, if the tricks should fail, start a regular siege, imprisoning the enemy inside the fortifications. The very fact that the emperor decided to leave the army under the command of individual strategists proves that the threat from enemies was under the control of the Byzantine forces. So what happened? What was the reason why a certain victory over a weak people turned into a shameful defeat of the imperial forces, as a result of which a foul and unclean tribe, as the Byzantine called them, frightened by the imperial power, conquered the Danube lands permanently? If Batbaian, faithful to Kubrat and righteous in Theophanes' opinion, succumbed to the godless Chazars, how was it possible that the Arch-Christian Byzantines failed to defeat Asparuh, who disobeyed his father? All the more so because the second of the listed brothers, the one who settled near Pentapolis on the Apennine Peninsula, had surrendered to their authority.

Apparently, it was all the fault of the Byzantines themselves. At first they were undecided in action, because horsemen was unable or unwilling to attack the enemy on the muddy ground. Incidentally, the author stresses once again that it was not the Bulgarians' own skills that saved them, but a natural obstacle preventing the Byzantines from attacking Bulgarian positions. Then the same Byzantine riders misunderstood the ruler's position completely, believing that he had lost faith in the success of his mission and that he was in the process of retreating. The army became confused, panic broke out and everyone fled, although, as the author emphatically points out, in reality nobody was chasing the Byzantines. At the sight of this unorganized, panicked retreat of the imperial army, the Bulgarians came out of the fortifications and pursued the Romans, most of whom they killed and wounded many. The chase continued south of the Danube until they reached the so-called Varna ${ }^{29}$, near Odyssos. Here, as the invaders realized that the place was naturally fortified, as it was protected from the back by the Danube, from the front by mountain passes (of nowadays Stara Planina), and from the side by Pontos, they subjugated local Slavic tribes. It was this attitude of the imperial troops, contrary to the orders and intentions of the ruler himself, that led the weak and

\footnotetext{
${ }^{29}$ A comprehensive overview of the subject matter related to the so-called Varna can be found in В. Плетньов, Варна през Средновековието, vol. I, Om VII до края на Х век, Варна 2008, p. 87-196.
} 
frightened people, who had only just believed themselves to be hopeless, to regain their strength and became bolder. Just as disobeying Kubrat's instruction made the Chazars bold, which led to the collapse and enslavement of Great Bulgaria, so the lack of determination and insubordination of the strategists against basileus orders made the Bulgarians bold, thus bringing defeat onto the empire.

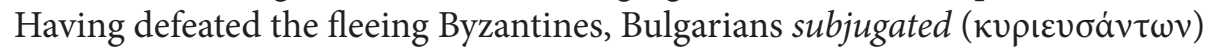
the land and the Slavs who lived there. Reflecting on the character of the invaders' rule, Theophanes used the same expression that appeared in his account of the joint reign of Kubrat's sons over their original homeland. The old khan wanted to maintain the same power that he himself exercised. Thus, as a result of mistakes and disobedience of the imperial army, the foul, unclean and bold nation, or rather its ruler, undeservedly achieved what he wanted, namely independent control (by implication as kúpıoc, because the noun is semantically associated with the verb quoted above) over other Byzantine lands. Of course, the text does not explicitly refer to Asparuh as the chieftain. However, the best proof of his significance for the events described above is the fact that the story of his settlement in Oglos was told as last, after listing Kubrat's four other sons in order from the eldest to the youngest, even though he was third. Undoubtedly, for the Byzantine authors he was the most important out of all the brothers.

Scholars conclude that the sources in question do not give Asparuh the title, nor do they make him the leader of Bulgarians ${ }^{30}$. Indeed, his name is not accompanied by any word describing his status among those Bulgarians who were his subjects. In the whole fragment concerning the early Bulgarian history only Kubrat and Baian are given any such titles. This may indicate that Khan's other sons were not held in any particular esteem. On the other hand, however, the text clearly states that some Bulgarian tribes were his subjects and he had them under his rule. This should not come as a surprise because this power, like that of his brothers, had been sanctioned by their father when they had lived together in the old Bulgaria, when he advised them to reign over it together, and so it was a fully legitimate government. However, the second of the above scholar statements requires a certain degree of revision. In the light of both sources, Kubrat's third son is identified with those Bulgarians who were his subjects and who came with him to the Danube. It was for them that he found a convenient and safe place to settle, which proves his strategic sense. It is interesting that the story begins with a reference to Asparuh himself and ends with a statement that the tribe settled there. In this context, the lack of any mention of his name further in the narrative proves that the other epithets appearing in both texts and concerning all Bulgarians also apply to him. It is significant that regarding Bulgarians, including Asparuh, Theophanes' account differs slightly, albeit significantly from that of Nicephorus. Theophanes calls Asparuh indirectly, as all Bulgarians under him, a foul and unclean, abhorrent,

${ }^{30}$ M.J. LeSZKA, Wizerunek..., p. 32-33. 
abject, bold and arrogant man. Nicephorus's account does not contain the above epithets, it only conveys the course of events.

Based on their experience to date and the positive role played by the natural obstacles in their clash with the Byzantines, the Bulgarians once again made sure that they were protected from all sides. As part of these activities, they also relocated the Slavs under their authority to the vulnerable border areas of their territory ${ }^{31}$. This allowed them in turn to spread unhindered in the controlled areas, and in consequence to feel so arrogant that they began to attack and ravage Byzantine territories south of the Stara Planina mountain range. As a result, as the Romans were put to shame for their many sins, the emperor was forced to make peace with them and to pay them an annual tribute. Why were the Byzantines disgraced? Because they did not make peace of their own accord but were forced to do so by the circumstances - the proud Romans had to recognize the superiority of the barbaric, pagan people! Because they, as our source testifies, were in the habit of making other peoples their taxpayers! And now they committed themselves to paying the newcomers every year in order to maintain peace with them, i.e. to halt their further expansion, which undoubtedly testified to the weakness of the empire ${ }^{32}$. The disgrace was all the more painful since the news was to reach both neighbors and distant peoples, i.e. to become common knowledge. After all, it was about an empire whose rulers claimed power over the entire oikoumene! And they lost to some insignificant, abhorrent and newly-arisen tribe who had just appeared (the sudden and recent appearance of Bulgarians on the Danube is emphasized twice in the text, basically forming a frame for the story of their conquest of territories south of the great river)! The Byzantines were disgraced because it emphasized their defeat, and in a broader Christian perspective - it revealed their sinful nature, which lost them the grace of God! It was obvious to Theophanes that ultimately the defeat of the imperial troops was a result of the sins of the Byzantines. Both individual, such as sluggishness, cowardice and insubordination of the imperial troops under Oglos, and common, concerning the inhabitants of the empire as a whole, perhaps also the ruler himself. It was obvious that if it had not been for these sins, the foul Bulgarians, who should have stayed in their ancestral homeland in the north, would have never managed to defeat the imperial army and humiliate Byzantium. Eventually, Theophanes tries to find some positives in this situation. He emphasizes the humility, philanthropy and devotion of the then emperor, who believed that what had happened was God's will and that it was better to establish peace than to continue the war with the invaders. That peace, which lasted until

${ }^{31}$ On securing the Danube region of Bulgarians' sovereignty cf. K. MARINOw, Góry Hemos jak miejsce schronienia, baza wypadowa i punkt obserwacyjny w świetle bułgarsko-bizantyńskich zmagań zbrojnych okresu wczesnego średniowiecza, BP 20, 2013, p. 5-8.

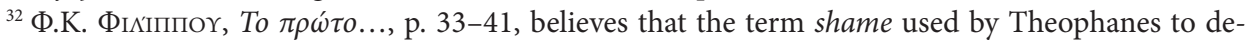
scribe the disgrace of the Romans should be understood as a waiver and recognition of the rule of Bulgarians in the lands they conquered and where they settled. 
the end of his reign, was probably a proof that he made the right decision. There was no other way out, so he had to accept the facts.

It is also only Theophanes who mentions that the Danube region is now under the rule of Bulgarians, whereas it used to be ruled by Romans. Nevertheless, it may be assumed that the eighth-century anonymous author used this particular phrase and Nicephorus simply omitted it ${ }^{33}$. This does not necessarily mean, however, that the Confessor did not apply the expression to his own time, as after all it was in line with the realities of the era in which he lived and worked. After all, at the beginning of the second decade of the ninth century Bulgarians still ruled over the lands that had originally been occupied by Asparuh. And they continued to attack the Byzantine territories, as did Asparuh, with growing intensity. This was due to the expansionist policy of Krum, the Bulgarian Khan (796/803-814) who wreaked havoc in the European domains of the Empire, even threatening Constantinople itself ${ }^{34}$, in 812-814, and thus precisely at the time when the Byzantine chronicler was working on his text. Therefore, the wording in the original account took on a new, current meaning in Theophanes' times. The threat from the Bulgarians, which Theophanes witnessed personally, resulted in a more deliberate approach to creating the image of Asparuh, Krum's predecessor on the Bulgarian throne, and in Theophanes' eyes - perhaps his direct ancestor. His attitude is more marked by contempt and aversion towards the empire's antagonists. Theophanes was more resentful towards Bulgarians because he was writing at the time of Krum's rule, and for this reason he found it was particularly justified. Unlike him, Nicephorus most likely completed his Historía sýntomos before taking over the Patriarchate in $806^{35}$, i.e. before Krum commenced military action against Byzantium and ultimately made his own name so infamous in Byzantine annals ${ }^{36}$. Undoubtedly, both texts were written from the their respective authors' current perspective, especially as far as the Confessor is concerned. For me, there is no doubt that his explicit dislike of Bulgarians, including their rulers, was strongly motivated by events related to the anti-Byzantine actions of Krum, who was a contemporary of the Byzantine chronicler. The great threat posed by Bulgarians, especially after 811 , had to stimulate interest in their origins and the circumstances of their settlement in the former lands of the empire. However, while in the case of Nicephorus, who completed his work before the outbreak of the Byzantine-Bulgarian conflict, we are dealing with a simple summary of the source from which

${ }_{33}^{33}$ С. В. Бешевлиев, Съобщението..., р. 37.

${ }^{34}$ More on the subject cf. В. ГюзЕлев, Езическа България, [in:] Ив. Божилов, В. ГюзЕлев, История на средновековна България, София 1999, p. 126-143.

35 The date of Nicephorus work is analyzed by Cyril MANGo (Introduction..., p. 8-12), who argues that it was written in the 780s. W. Treadgold, The Middle Byzantine..., p. 27, believes that it was the 790s.

${ }^{36}$ More about his image in these sources cf. П. Ангелов, България и българите в представите на византийците (VII-XIV век), София 1999, p. 161-168; M.J. LeszKA, Wizerunek..., p. 36-55. 
he drew and whose author merely wanted to speak of the dominion of the Huns (as they are called) and the Bulgarians and their affairs, Theophanes is different in that respect. He begins his narrative of the Asparuh's appearance in the Lower Danube region with a sentence that unambiguously directs the course of the story - In this year, too, the tribe of the Bulgarians assailed Thrace. Already at the outset, Bulgarians are presented as aggressors, and the reader is negatively disposed towards them. Stigmatizing the sins of Kubrat's sons and the misfortune they brought upon the Byzantines, Theophanes implicitly points to Krum himself, who in his opinion was the epitome of a terrible, barbaric threat to the empire. His destructive actions were, after all, a distant consequence of the settlement of Bulgarians on the lower Danube, and he himself was, like Asparuh and his people, a bloodthirsty pagan, not guided by the noble principles of the Christian faith. If the Bulgarian settlers had not come to the territory of the empire, if they had remained in the north, where their true homeland was, then Krum and his invasions would not have occurred, Byzantine blood would not have been spilled and the ungodly pride of the foul and abject invaders would not have prevailed. Undoubtedly, therefore, the personal experience of the difficult times in which the Byzantine author worked exacerbated his views on the northern neighbors of the empire.

Even if we assume that the story of Kubrat and his will is a literary topos ${ }^{37}$, it is worth noting that the anonymous author (Trajan the Patrician?) from the first quarter of the eighth century, whose account became the basis of Theophanes' narrative, gave the names of Bulgarian rulers - Kubrat and Asparuh - confirmed by an independent Bulgarian source, called the Nominalia of the Bulgarian Khans ${ }^{38}$.

${ }^{37}$ Cf. W. Pohl, Die Awaren. Ein Steppenvolk in Mitteleuropa 567-822 n. Chr., München 1988, p. 281; TNDS.SG, vol. III, p. 93, an. 32. More on mythological tales and their interpretation as a reflection of real practices vide Ст. Йорданов, Обичаят "свещена пролет" у прабългарите и механизмбт напреселенията им в Северното Причерноморие и Балканите, [in:] БСП, vol. II, p. 30-51, esp. 33-34, 46; cf. А. Николов, Българската историческа топика: “Българи-скити”, “славяни-скити”, [in:] БСП, vol. VII, p. 235-236. In turn В. БЕшевлиев, Съобщението..., p. 48, considers that the presence of similar themes in other traditions does not prove them to be untrue, merely as evidence of literary transmission, but, on the contrary, indicates the universality and legitimacy of the advice given by Kubrat to his sons. He only considers the number of the brothers (five) to be legendary.

${ }^{38}$ More on this source cf. М. Москов, Именник на българските ханове (Ново тълкуване), София 1988. It should be pointed out, however, that the names Kurt and Bezmer are rather unlikely to be derived from Kubrat and Batbaian, respectively - vide Б. Симеонов, Прабългарска ономастика, Пловдив 2008, p. 143, 146. Despite this, there is no doubt that three of the rulers mentioned by Theophanes and Nicephorus correspond to those appearing in the Old Bulgarian source. I leave aside the question of whether Asparuh really was the name of the Bulgarian Khan - cf. Ст. ЙордАнов, Паисий или Никифор: за личното име и титлите на основателя на Пгрвото българско иарство, [in:] Българистични проучвания. 9. Актуални проблеми на българистиката и славистиката. Осма международна научна сесия, Велико Търново, август 2002 г., Велико Търново 2003, p. 70-81. 
Moreover, according to Vesselin Beševliev, based on the correlation of his account with other known sources, it is possible to prove the existence of four out of the five brothers mentioned there ${ }^{39}$. Other scholars accept that three of them might have been real - Batbaian, Kotrag (possibly a legendary eponym of the Kotrags) and Asparuh - concluding that they might be the leaders of the three basic groups in Kubrat's Bulgaria, corresponding to the three parts into which it disintegrated after his death ${ }^{40}$. Despite these divergent views, it seems that the source seems to indicate that the author had considerable knowledge of the early Bulgarian history.

To conclude, Theophanes looked at the migration and permanent settlement of Bulgarians on the Lower Danube through the prism of the experience of the second decade of the ninth century, when he was writing his work, and when Bulgarians posed a serious threat to the Byzantine Empire. In order to express his views on the empire's northern neighbors, he deliberately introduced a series of highly significant epithets into the earlier source on which this part of his Chronography is based, which lent this account a clear ideological dimension.

Translated by Katarzyna Gucio

\section{Bibliography}

\section{Primary Sources}

The Chronicle of Theophanes Confessor. Byzantine and Near Eastern History AD 284-813, trans. et ed. C. Mango, R. Scott, G. Greatrex, Oxford 1997.

A New English Translation of the Septuagint, ed. A. Pietersma, B.G. Wright, Oxford 2007.

Nicephori Patriarchae Constantinopolitani breviarium historicum, ed. C. MANGo, Washingtoniae 1990 [= Corpus fontium historiae byzantinae $]$.

Novum Testamentum Graece, ed. B. Aland, K. Aland, J. Karavidopoulos, C.M. Martini, B.M. Metzger, ${ }^{28}$ Stuttgart 2012.

The Pocket Interlinear New Testament. Numerically Coded to Strong's Exhaustive Concordance, ed. J.P. Green, Grand Rapids 1988.

Septuaginta. Id est Vetus Testamentum graece iuxta LXX interpretes, vol. I-II, ed. A. RAHLFs, rec. R. HANHART, Stuttgart 2006.

Testimonia najdawniejszych dziejów Słowian. Seria grecka, vol. III, Pisarze z VII-X wieku, ed. A. Brzóstkowska, W. Swoboda, Warszawa 1995.

Theophanis Chronographia, ed. C. DE Boor, vol. I, Lipsiae 1883 [= Corpus scriptorum historiae byzantinae].

${ }^{39}$ В. БЕшевлиев, Съобщението..., p. 45, 48. Ст. ЙордАнов, За социално-политическата организация..., p. 49-69, supports this view through interpretations relating to the organization of Great Bulgaria.

${ }^{40}$ Ив. Венедиков, Митове..., р. 39-43; В. ГюзЕлев, Езическа Бблгария..., р. 81-82; А. Николов, Българската историческа топика..., p. 235-236. 
Trachiniae, [in:] The Tragedies of Sophocles, trans. R.С. Јевв, Cambridge 1917, p. 277-323.

Trachiniai, [in:] Sophoclis tragoediae, vol. II, Trachiniae, Antigone, Philoctetus, Oedipus Coloneus, ed. R.D. DAWE, Leipzig 1985 [= Bibliotheca scriptorum Graecorum et Romanorum Teubneriana], p. $1-45$.

\section{Secondary Literature}

Alexander P.J., The Patriarch Nicephorus of Constantinople. Ecclesiastic Policy and Image Worship in Byzantine Empire, Oxford 1958.

Andreev J., Asparuch, [in:] J. Andreev, I. Lazarov, P. Pavlov, Koj koj e v Srednovekovna Bălgarija (Treto dopălneno i osnovno preraboteno izdanie), Sofija 2012, p. 54-59.

Andreev J., Lalkov M., Istoričeski spravočnik. Bălgarskite chanove i care. Ot chan Kubrat do car Boris III, Veliko Tărnovo 1996.

ANGELov P., Bălgarija i bălgarite v predstavite na vizantijscite (VII-XIV vek), Sofija 1999.

Angold M., Withby M., Historiography, [in:] The Oxford Handbook of Byzantine Studies, ed. E. Jefrreys, J. Haldon, R. Cormack, Oxford 2008, p. 838-852.

Atanasov G., Kan Asparuch - edno novo načalo, [in:] Bălgarska nacionalna istorija, vol. III, Părvo bălgarsko carstvo (680-1018), ed. P. PAVLov, Veliko Tărnovo 2015, p. 13-67.

Atanasov G., Părvostroitelite na bălgarskata dăržavnost. Organa, Kubrat, Asparuch, Tervel, Sofija 2015.

Atanasov G., Starata Velika Bălgarija i kan Kubrat, [in:] Bălgarska nacionalna istorija, vol. II, Drevnite bălgari, Starata Velika Bălgarija i nejnite naslednici v Iztočna Evropa prez Srednovekovieto, ed. P. PAvlov, Veliko Tărnovo 2013, p. 107-170.

Beck H.-G., Kirche und theologische Literature im byzantinischen Reich, München 1977.

BeŠEvliev V., Săobštenieto na Teofan za osnovavaneto na bălgarskata dăržava, “Известия на Народния музей - Варна” / "Izvestija na Narodnija Muzej - Varna” 18 (33), 1982, p. 31-53.

Betri M., The Making of Christian Moravia (858-882). Papal Power and Political Reality, LeidenBoston 2014.

Brubaker L., Haldon J., Byzantium in the Iconoclast Era (ca 680-850): the Sources. An Annotated Survey, Aldershot 2001.

Сісноска H., Nikefor, [in:] Encyklopedia kultury bizantyńskiej, ed. O. Jurewicz, Warszawa 2002, p. 370-371.

Cichocka H., Teofanes Wyznawca, [in:] Encyklopedia kultury bizantyńskiej, ed. O. JuREwicz, Warszawa 2002, p. 466-467.

ČıčUnov I.S., Vizantijskie istoričeskie sočinenija: Chronografija Feofana, Breviarij Nikifora, Moskva 1980.

Dostálová R., MEGALE MORABIA, “Byzantinoslavica” 27, 1966, p. 344-349.

L'écriture de la mémoire. La littératuré de l'historiographie, ed. P. Odorico, P. Agapitos, M. HinterBERGER, Paris 2006 [= Dossiers Byzantins, 6].

Frejberg L.A., Popova T., Vizantijskaja literatura epochi razcveta IX-XV vv., Moskva 1978.

GJuzelev V., Chan Asparuch und die Gründung des bulgarischen Reiches, [in:] Miscellanea Bulgarica. Mitteilungen des Bulgarischen Forschungsinstitutes in Österreich, vol. III, ed. V. GJUZELEv, Wien 1986, p. 25-46. 
Gjuzelev V., Ezičeska Bălgarija, [in:] I. Božılov, V. Gjuzelev, Istorija na srednovekovna Bălgarija, Sofija 1999, p. 126-143.

GJuzelev V., Fol A., Chan Asparuch, [in:] Beležiti bălgari, vol. I, 681-1396, ed. B. Čolpanov, V. GJuZELEV, Sofija 1967, p. 7-25.

History as Literature in Byzantium. Papers from the Fortieth Spring Symposium of Byzantine Studies, University of Birmingham, April 2007, ed. R. MACRIDES, Aldershot 2010.

Hrissimov N., Bălgarskata dăržavnost i Starata rodina (VII-XI v.): taka narečenata Černa Bălgarija, [in:] Bălgarska nacionalna istorija, vol. II, Drevnite bălgari, Starata Velika Bălgarija i nejnite naslednici v Iztočna Evropa prez Srednovekovieto, ed. P. PAvlov, Veliko Tărnovo 2013, p. 249-296.

Hunger H., Die Hochsprachliche Profane Literatur der Byzantiner, vol. I, Philosophie - Rhetorik - Epistolographie - Gesschichtsschreibung - Geographie, München 1978.

JoRDANov St., Običajat "sveštena prolet" u prabălgarite i mechanizmăt na preselenijata im v Severnoto Pričernomorie i Balkanite, [in:] Bălgarite v Severnoto Pričernomorie. Izsledvanija i materiali, vol. II, Veliko Tărnovo 1993, p. 30-51.

Jordanov St., Paisij ili Nikifor: za ličnoto ime i titlite na osnovatelja na Părvoto bălgarsko carstvo, [in:] Bălgaristični proučvanija. 9. Aktualni problemi na bălgaristikata i slavistikata. Osma meždunarodna naučna sesija, Veliko Tărnovo, avgust 2002 g., Veliko Tărnovo 2003, p. 70-81.

Jordanov St., Za socialno-političeskata organizacija na Kubratova Velika Bălgarija: I. Plemennata obštnost na unogundurite, Patria Onoguria i Velika Bălgarija, [in:] Bălgarite v Severnoto Pričernomorie. Izsledvanija i materiali, vol. V, Veliko Tărnovo 1996, p. 49-69.

Jurewicz O., Historia literatury bizantyńskiej. Zarys, Wrocław 1984.

Kaldellis A., Ethnography after Antiquity. Foreign Lands and Peoples in Byzantine Literature, Philadelphia 2013.

Karayannopulos J., Weiss G., Quellenkunde zur Geschichte von Byzanz (324-1453). Methodik. Typologie. Randzonen, vol. II, Wiesbaden 1982.

Kazhdan A.P., Nikephoros I, [in:] The Oxford Dictionary of Byzantium, vol. III, ed. A.P. Kazhdan, Oxford-New York 1991, p. 1477.

Kazhdan A.P., Theophanes the Confessor, [in:] The Oxford Dictionary of Byzantium, vol. III, ed. A.P. Kazhdan, Oxford-New York 1991, p. 2063.

Kazhdan A.P., Sherry L.F., Angelidi C., A History of Byzantine Literature (650-850), Athens 1999.

Kompa A., Gnesioi filoi: the Search for George Syncellus' and Theophanes the Confessor's Own Words, and the Authorship of Their Oeuvre, "Studia Ceranea" 5, 2015, p. 155-230.

Leszka M.J., Wizerunek władców Pierwszego Państwa Bułgarskiego w bizantyńskich źródłach pisanych (VIII - pierwsza połowa XII wieku), Łódź 2003 [= Byzantina Lodziensia, 7].

LitaVrin G.G., K probleme stanovelenija bolgarskogo gosudarstva, [in:] G.G. LitaVRIn, Vizantija i slavjane (sbornik statej), Sankt-Peterburg 1999, p. 192-217.

Mango C., Introduction, [in:] Nicephori Patriarchae Constantinopolitani breviarium historicum, ed. C. Mango, Washingtoniae 1990, p. 1-31.

MARINOw K., Góry Hemos jak miejsce schronienia, baza wypadowa i punkt obserwacyjny w świetle bułgarsko-bizantyńskich zmagań zbrojnych okresu wczesnego średniowiecza, "Balcanica Posnaniensia. Acta et Studia" 20, 2013, p. 5-17.

Mosкov M., Imennik na bălgarskite chanove (Novo tălkuvane), Sofija 1988. 
Nikolov A., Bălgarskata istoričeska topika: "Bălgari-skiti”, "slavjani-skiti”, [in:] Bălgarite v Severnoto Pričernomorie. Izsledvanija i materiali, vol. VII, Veliko Tărnovo 2000, p. 233-252.

O'Connell P., The Ecclesiology of St. Nicephorus I, Rome 1972.

Philippou Ph.K., To proto boulgariko kratos kai e Byzantine Oikoumenike autokratoria (681-852). Byzantinoboulgarikes politikes scheseis, Thessalonike 2001.

Pletnjov V., Varna prez Srednovekovieto, vol. I, Ot VII do kraja na X vek, Varna 2008.

Pohl W., Die Awaren. Ein Steppenvolk in Mitteleuropa 567-822 n. Chr., München 1988.

RAšEv R., Kulturata na Starata Velika Bălgarija - archeologičeski pametnici, [in:] Bălgarska nacionalna istorija, vol. II, Drevnite bălgari, Starata Velika Bălgarija i nejnite naslednici v Iztočna Evropa prez Srednovekovieto, ed. P. Pavlov, Veliko Tărnovo 2013, p. 171-248.

Rochow I., Byzanz im 8. Jahrhundert in der Sicht des Theophanes. Quellenkritisch-Historischer Kommentar zu den Jahren 715-813, Berlin 1991.

Scotт R., Text and Context in Byzantine Historiography, [in:] A Companion to Byzantium, ed. L. James, Chichester 2010, p. 251-262.

Simeonov B., Prabălgarska onomastika, Plovdiv 2008.

Stepanov Cv., O lokalizacii “Velikoj Bolgarii” Kubrata, "Bulgarian Historical Review / Revue bulgare d'histoire" 24.2, 1995, p. 5-11.

Swoводa W., Powstanie państwa bułgarskiego na tle słowiańskich procesów państwowotwórczych na Bałkanach, [in:] 1300-lecie państwa bułgarskiego 681-1981. Materiały z sesji naukowej, ed. T. Zdancewicz, Poznań 1983, p. 67-76.

Todorov B.A., Byzantine Myths of Origins and Their Functions, "Studia Slavica et Balcanica Petropolitana" 2, 2008, p. 64-72.

“Travaux et Mémoires" 19, Studies in Theophanes, ed. M. Jankowiak, F. Montinaro, Paris 2015.

Travis J., The Defense of the Faith. The Theology of Patriarch Nikephoros of Constantinople, Brookline 1984.

Treadgold W., The Middle Byzantine Historians, New York-Basingstoke 2013.

Trubačev O.N., Ėtnogenez i kul'tura drevnejšich slavjan. Lingvističeskie issledovanija, ${ }^{2}$ Moskva 2003.

Vachкova V., Danube Bulgaria and Khazaria as Parts of Byzantine Oikumene, [in:] The Other Europe in the Middle Ages. Avars, Bulgars, Khazars and Cumans, ed. F. Curta, R. Kovalev, Leiden 2008, p. 339-362.

VAVŘínek V., Encyklopedie Byzance, coop. P. BAlcÁrka, Praha 2011.

Venedikov I., Mitove na bălgarskata zemja, vol. I, Mednoto gumno (Vtoro preraboteno izdanie), Stara Zagora 1995.

Wasilewski T., Kontrowersje wokół powstania i najstarszych dziejów państwa bułgarskiego, [in:] Trzynaście wieków Bułgarii. Materiały polsko-bułgarskiej sesji naukowej, Warszawa 28-30 X 1981, ed. J. SiATKOWSKI, Wrocław 1983, p. 181-189.

\footnotetext{
Abstract. The Bulgarians' settlement in the Lower Danube area constituted one of the most significant events in the history of the Balkan Peninsula in the Middle Ages. The Danube Bulgarias rise and its territorial expansion changed the political situation in this area. The Bulgarians became Byzantium's chief opponents in the struggle for establishing ascendancy over the Balkan Peninsula. The analysis of Theophanes' Chronography, which remains, in addition to the account by Patriarch Nicephorus, the main source of information about these events supports the conclusion that this
} 
Byzantine author took a very negative view of the effects of the arrival of these nomads in the former Byzantine territories. Although this account has been analysed in detail by a number of scholars, these authors have paid no attention to the key role of the tale of Khan Kubrat and the disobedience of his five sons who failed to remain faithful to his last wish. The significance of the personal experiences of Theophanes, who witnessed the Bulgarian expansion during the era of Khan Krum, is also omitted from today's discussion of these issues. These experiences contributed to the way in which he viewed the migration of the ancestors of the distinguished Bulgarian ruler. The chronicler may thus be considered to have offered a very clear view of what the readers should think of the Bulgarians' arrival in the Balkan territories.

Keywords: Kubrat, Asparuh, Kotrag, Theophanes the Confessor, Onglos, medieval Bulgaria, Byzantine historiography, myths and legends of origins, Byzantine ideology

Kirił Marinow

Uniwersytet Łódzki

Wydział Filozoficzno-Historyczny

Instytut Historii

Katedra Historii Bizancjum

ul. Kamińskiego 27a

90-219 Łódź, Polska/Poland

cyrillus.m@wp.pl 